\title{
Deskripsi Kemampuan Penalaran Adaftif Siswa di SMP Negeri 5 Purwokerto Ditinjau dari Keaktifan Belajar Siswa
}

\author{
Hasya Putri Afifian ${ }^{1}$, Eka Setyaningsih ${ }^{2}$ \\ ${ }^{1,2}$ Program Studi Pendidikan Matematika, Universitas Muhammadiyah Purwokerto \\ hasyaputriafifian@gmail.com, ekasetyaning13@gmail.com
}

\begin{abstract}
ABSTRAK
Penelitian ini bertujuan untuk mendeskripsikan kemampuan penalaran adaptif siswa di SMP Negeri 5 Purwokerto yang ditinjau dari keaktifan belajar siswa pada materi sistem persamaan linear dua variabel. Penelitian ini menggunakan metode penelitian kualitatif dan menggunakan model Miles and Huberman yang meliputi reduksi data (data reduction), penyajian data (display data) dan kesimpulan (verification/conclusion drawing). Sumber data dalam penelitian ini adalah siswa kelas VIII H. Subjek penelitian diperoleh dengan menggunakan teknik purposive sampling, siswa dikategorikan ke dalam tiga kategori, yaitu siswa dengan kategori keaktifan belajar tinggi, sedang dan rendah. Masing-masing kategori dipilih tiga siswa untuk keperluan penelitian. Metode pengumpulan data dalam penelitian ini menggunakan angket, tes, wawancara dan dokumentasi. Berdasarkan hasil penelitian dapat dikatakan bahwa siswa yang memiliki keaktifan belajar tinggi sudah mampu dan memenuhi tiga dari lima indikator kemampuan penalaran adaptif dengan tepat, siswa yang memiliki keaktifan belajar sedang belum sepenuhnya memenuhi indikator kemampuan penalaran adaptif dengan tepat dan siswa yang memiliki keaktifan belajar rendah belum mampu dan menguasai dengan tepat indikator kemampuan penalaran adaptif.
\end{abstract}

Kata kunci: Keaktifan Belajar, Kemampuan Penalaran Adaptif, SMP Negeri 5 Purwokerto

\begin{abstract}
This study aims to describe the adaptive reasoning skills of students in SMP Negeri 5 Purwokerto in terms of student learning activeness in the subject system of two-variable linear equations. This study uses qualitative research methods and uses the Miles and Huberman model, which includes data reduction, data presentation (display data) and conclusions (verification/conclusion drawing). Sources of data in this study were students of class VIII H. The research subjects were obtained using purposive sampling techniques, and students were categorized into three categories, namely students with high, medium and low learning activeness categories. Each group was selected by three students for research purposes. Data collection methods in this study used questionnaires, tests, interviews and documentation. Based on the results of the study it can be said that students who have high learning activeness are able and meet three of the five indicators of adaptive reasoning skills appropriately, students who have active learning are not yet adequately fulfilling indicators of adaptive reasoning skills appropriately, and students who have low learning activeness have not been able to and mastering precisely the indicators of adaptive reasoning abilities.
\end{abstract}

Key words: Learning Activeness, Adaptive Reasoning Skills, SMP Negeri 5 Purwokerto

\section{Pendahuluan}

Matematika merupakan pelajaran yang bagi sebagian pelajar dianggap atau dipandang sebagai pelajaran yang sulit, karena dalam matematika seorang siswa tidak hanya diberikan tentang bagaimana memahami suatu permasalahan dalam soal tetapi juga dibutuhkan yang namanya intuisi dan memahami aturan serta prosedur penyelesaian. Dalam menyelesaikan persoalan matematika, dibutuhkan suatu keterampilan, kompetensi, serta kemampuan metakognitif dalam diri seorang pelajar (Donovan, 2005). Salah satu kemampuan metakognitif yang harus dikembangkan sejak dini yaitu pemahaman atau penalaran. Penalaran tidak hanya digunakan seseorang dalam memecahkan masalah secara logis (Maharani: 2018, Rosyidi: 2018).

Ada dua jenis penalaran yaitu penalaran induktif dan penalaran deduktif (Depiknas, 2006). Penalaran induktif merupakan penalaran yang memainkan peran penting dalam pengembangan serta penerapan matematika. Melalui penalaran induktif dapat dihasilkan suatu kesimpulan 
yang benar terkait dengan contoh khusus yang dipelajari, tetapi kesimpulan tersebut tidak terjamin untuk generalisasi. Sedangkan penalaran deduktif merupakan proses berpikir yang menghubungkan fakta atau kejadian umum yang sebelumnya telah dibuktikan kebenarannya menuju kepada suatu kesimpulan yang bersifat khusus. Kesimpulan yang dimunculkan dalam penalaran deduktif dimulai dengan premis-premis (proporsi umum).

Kaitannya dengan pemaparan tersebut adalah dalam penelitiannya NRC (2001) memperkenalkan satu penalaran yang mencakup penalaran induktif dan penalaran deduktif yaitu penalaran adaptif. Penalaran adaptif sendiri merupakan kemampuan seseorang untuk berpikir logis, menerka jawaban, memberikan penjelasan mengenai konsep dan prosedur jawaban yang digunakan serta menilai kebenarannya secara matematis. Donovan \& Bransford (2016) menyatakan bahwa penalaran adaptif mengacu kepada kemampuan seseorang untuk berpikir logis, reflektif, penjelasan dan pembenaran. Sedangkan menurut Kilpatrick et.al. (2001) penalaran adaptif diartikan sebagai kapasitas berpikir secara logis yang berkaitan dengan hubungan antara konsep dan situasi.Killpatrick, Swafford \& Findell (2001) mengemukakan terdapat beberapa indikator kemampuan penalaran adaptif, yaitu:1) kemampuan dalam mengajukan dugaan atau hipotesis, 2) mampu memberikan alasan mengenai jawaban yang diberikan, 3) mampu menarik kesimpulan dari suatu pernyataan, 4) mampu memeriksa kesahihan suatu argumen, dan 5) mampu menemukan pola dari suatu gejala matematis

Killpatrick, Swafford \& Findell dalam penelitiannya mengemukakan ada lima kompetensi dalam pembelajaran matematika, yaitu pemahaman konsep, kemahiran prosedural, kompetensi strategi, penalaran adaptif dan sikap produktif (Herniyati, 2017). Dari kelima kompetensi yang dikemukakan tersebut, ada kompetensi yang perlu dikembangkan siswa sejak dini yaitu kompetensi penalaran adaptif, karena dengan adanya kemampuan penalaran adaptif siswa dapat memiliki kemampuan berpikir logis yang dilakukan dengan menghubungkan beberapa konsep dan situasi dengan tujuan untuk menarik kesimpulan serta memberikan alasan dan menilai kebenaran dari suatu pernyataan.Pada saat mengerjakan soal matematika siswa tidak lepas dari proses berpikir serta menalar, dimana siswa berusaha untuk mencari cara penyelesaian dan mencari solusi dari permasalahan matematika.

Berdasarkan pendapat yang diberikan oleh para ahli, maka dapat disimpulkan bahwa penalaran adaptif merupakan kemampuan seseorang untuk berpikir logis dalam mengusulan suatu dugaan atau hipotesis penyelesaian dari suatu masalah, memberikan penjelasan mengenai dugaan yang digunakan, menemukan pola dari suatu jawaban, menilai kebenaran secara matematis dan menarik suatu kesimpulan dari sebuah jawaban. Indikator kemampuan penalaran adaptif meliputi: 1) kemampuan dalam mengajukan dugaan atau hipotesis; 2) mampu memberikan alasan mengenai jawaban yang diberikan; 3) mampu menarik kesimpulan dari suatu pernyataan; 4) mampu memeriksa kesahihan suatu argumen; dan 5) mampu menemukan pola dari suatu gejala matematis

Pengetahuan yang dimiliki oleh siswa untuk melalui proses berpikir dan menalar ini diperoleh dari proses belajar mengajar, dimana dalam proses belajar siswa tidak hanya dapat mengingat apa yang dipelajari tetapi juga mengalami. Hamalik (2006: 27) berpendapat bahwa belajar merupakan suatu proses bukan suatu tujuan atau hasil. Proses belajar mengajar akan dikatakan efektif apabila siswa mendominasi aktivitas pembelajaran. Belajar tidak cukup hanya mendengar dan melihat tetapi juga berlangsung aktifitas membaca, menanya, mengkomunikasikan, diskusi, menyimpulkan dan memanfaatkan peralatan yang ada.Berdasarkan hal tersebut, peran guru dalam upaya menumbuhkan keaktifan belajar dalam 
proses pembelajaransangatlah penting agar kegiatan pembelajaran dapat berlangsung secara dua arah dan lebih efektif.

Dalam pembelajaran, keaktifan siswa merupakan suatu penunjang tecapainya hasil yang optimal. Keaktifan siswa dalam proses belajar mengajar dapat diamati dari keterlibatan fisik siswa maupun secara intelektual emosional atau psikis siswa (Dimyati dalam Novasari, 2017:12). Keterlibatan fisik siswa dapat berupa kegiatan yang mudah diamati seperti membaca, menulis, mendengarkan dan memperhatikan. Sedangkan keterlibatan psikis mengarah kepada kondisi emosional siswa yang mana sulit untuk diamati.

Sudjana (1989) mengemukakan bahwa belajar adalah proses yang aktif, proses yang diarahkan kepada tujuan, proses berbuat melalui berbagai pengalaman dan proses mereaksi terhadap semua situasi yang ada di sekitar individu. Hamalik (2006), belajar merupakan suatu proses perubahan tingkah laku individu melalui interaksi dengan lingkungan. Berdasarkan beberapa pengertian yang telah dikemukakan oleh para ahli, dapat disimpulkan bahwa keaktifan belajar adalah keterlibatan siswa selama proses pembelajaran yang ditandai dengan perubahan tingkah laku ke arah yang lebih baik melalui berbagai kegiatan yang terjadi di dalam kelas diantaranya melihat, mengamati, memahami sesuatu, berpendapat di dalam kelas.

Nana (Novasari, 2017), mengemukakan pendapatnya tentang keaktifan belajar yang dapat dilihat dalam hal: 1) turut serta dalam melaksanakan tugas belajarnya; 2) terlibat dalam pemecahan masalah; 3) bertanya kepada siswa lain atau kepada guru apabila tidak memahami persoalan yang dihadapinya; 4) berusaha mencari berbagai informasi yang diperlukan untuk pemecahan masalah; 5) melaksanakan diskusi kelompok sesuai dengan petunjuk guru; 6) menilai kemampuan dirinya dan hasil-hasil yang diperolehnya; 7) melatih diri dalam memecahkan soal atau masalah sejenisnya; dan 8) kesempatan menggunaan atau menerapkan apa yang telah diperolehnya dalam menyelesaikan tugas atau persoalan yang dihadapinya.

Keaktifan belajar dapat ditunjukkan dengan keikutsertaan siswa dalam proses pembelajaran yang bertujuan agar siswa memiliki keberhasilan dalam belajar. Lestari (dalam Novasari, 2017) mengemukakan terdapat beberapa indikator keaktifan belajar yaitu: 1) menyatakan pendapat; 2) mengajukan pertanyaan; 3) menanggapi pendapat orang lain; 4) mengerjakan tugas dengan baik; 5) terlibat dalam tugas belajar; 6) turut serta dalam kegiatan penyelesaian masalah; 7) melaksanakan diskusi kelompok; dan 8) berani maju didepan kelas. Mengacu pada beberapa pengertian, ciri dan indikator di atas, maka peneliti mengambil indikator keaktifan belajar adalah 1) bertanya kepada siswa lain atau kepada guru apabila tidak memahami persoalan yang dihadapi; 2) terlibat dalam kegiatan penyelesaian masalah dan atau tugas belajar melalui menyatakan pendapat dan menanggapi orang lain; 3) melaksanakan diskusi kelompok dan berani tampil di depan kelas untuk menilai kemampuan dirinya dan hasil-hasil yang diperolehnya; dan 4) mengerjakan tugas dengan baik dengan menggunakan atau menerapkan apa yang telah diperolehnya dalam menyelesaikan tugas atau persoalan yang dihadapinya.

Pentingnya keaktifan belajar yang harus dimiliki siswa memiliki manfaat positif bagi siswa. Dengan adanya keaktifan belajar dan penalaran adaptif yang dimiliki siswa, guru dapat merancang pembelajaran yang tepat untuk siswa serta dapat memberikan tindak lanjut agar siswa mampu memiliki tingkat keaktifan belajar dan penalaran adaptif yang baik. 


\section{AlphaMath \\ Journal of Mathematics Education, 5(2) November 2019}

\section{Metode Penelitian}

Jenis penelitian ini adalah penelitian deskriptif kualitatif. Penelitian dilaksanakan pada semester genap tahun ajaran 2018/2019 di kelas VIII H SMP Negeri 5 Purwokerto. Subjek penelitian yang dipilih yaitu 9 siswa yang terdiri dari 3 orang dengan keaktifan belajar tinggi, 3 orang dengan keaktifan belajar sedang dan 3 orang dengan keaktifan belajar rendah. Pemilihan subjek dilakukan dengan memberikan angket keaktifan belajar dan tes kemampuan penalaran adaptif untuk kemudian dilakukan wawancara. Adapun prosedur pengumpulan data yakni dengan membagikan angket keaktifan belajar kepada 33 siswa kelas VIII H serta soal tes kemampuan penalaran adaptif, kemudian dipilih 9 subjek berdasarkan kategori keaktifan belajar. Dasar pengkategorian siswa berdasarkan kategori tinggi, sedang dan rendah adalah sebagai berikut.

Tabel 1. Kategori Keaktifan Belajar

\begin{tabular}{lc}
\hline Kategori Keaktifan Belajar & Batas Kelompok \\
\hline Keaktifan belajar tinggi & $62<X$ \\
\hline Keaktifan belajar sedang & $50 \leq X \leq 62$ \\
\hline Keaktifan belajar rendah & $X<50$ \\
\hline
\end{tabular}

Selanjutnya dilakukan wawancara terhadap 9 subjek yang telah dipilih berdasarkan kategori keaktifan belajarnya. Wawancara dilakukan setelah subjek mengisi angket keaktifan belajar dan tes kemampuan penalaran adaptif. Untuk melihat keabsahan data dilakukan dengan triangulasi tekhnik.

\section{Hasil dan Pembahasan}

\section{Kemampuan Penalaran Adaptif dengan Keaktifan Belajar Tinggi}

Siswa dengan keaktifan belajar tinggi cukup mampu dalam memahami soal dengan baik. Pada soal keempat yang memuat indikator kemampuan dalam mengajukan dugaan atau hipotesis, siswa mampu menemukan persamaan kedua dengan tepat. Siswa mampu menduga persamaan kedua yang terbentuk dari selesaian yang ada, sehingg dapat dikatakan siswa mampu dalam mengajukan dugaan atau hipotesis. Pada soal ketiga yang memuat indikator kemampuan dalam memberikan alasan, beberapa siswa belum mampu menuliskan alasan yang tepat dari jawaban yang diberikan. Saat diwawancara siswa mampu menjelaskan langkah mana yang menunjukkan kesalahan akan tetapi siswa masih merasa kebingungan dalam menuliskan alasan yang tepat dengan jawaban, sehingga beberapa siswa belum mampu dalam memberikan alasan terkait jawaban yang diberikan. Pada soal kedua yang memuat indikator mampu menarik kesimpulan, siswa mampu menguraikan beberapa pernyataan menjadi suatu kesimpulan yang tepat. Dari hal tersebut dapat dikatakan siswa mampu menarik kesimpulan dari soal yang diberikan. Pada soal pertama yang memuat indikator mampu memeriksa kesahihan atau kebenaran suatu argumen, beberapa siswa belum sepenuhnya mampu menguraikan bukti yang dibutuhkan untuk memeriksa kesahihan argumen yang dinyatakan. Beberapa siswa cenderung tidak mampu menalar dengan tepat tentang penyelesaian jawaban berdasarkan informasi yang diketahuti, sehingga beberapa siswa belum mampu memeriksa kesahihan suatu argumen. Pada soal kelima yang memuat indikator kemampuan dalam menemukan pola penyelesaian, beberapa siswa sudah mampu sepenuhnya dalam menguraikan informasi yang ada pada soal menjadi sebuah pola permisalan. Meskipun dalam proses menghitung beberapa siswa masih ada yang kurang teliti, akan tetapi saat diwawancarai siswa bisa menjelaskan dengan tepat penyelesaian jawaban berdasarkan hal-hal yang diketahui. Dari hal tersebut dapat dikatakan siswa mampu menemukan pola pada suatu gejala matematis yang tepat. 


\section{Kemampuan Penalaran Adaptif dengan Keaktifan Belajar Sedang}

Terdapat beberapa siswa dengan keaktifan belajar sedang masih bingung dalam memahami soal. Beberapa siswa menuliskan dan menjelaskan jawaban dengan kurang lengkap atau menuliskan bentuk lain dari persamaan yang ada pada soal. Pada soal pertama yang memuat indikator kemampuan mengajukan dugaan atau hipotesis, beberapa siswa mampu menguraikan jawaban dengan tepat. Meskipun dalam menguraikan langkah-langkah yang dilakukan masih belum lengkap, beberapa siswa mampu menduga persamaan kedua dari selesaian yang telah ditentukan. Pada soal ketiga yang memuat indikator mampu dalam memberikan alasan, beberapa siswa masih belum mampu dalam menuliskan alasan yang tepat dari jawaban yang diberikan, sehingga beberapa siswa belum memberikan alasan secara jelas tentang jawaban yang diberikan. Pada soal kedua yang memuat indikator kemampuan dalam menarik kesimpulan, siswa mampu menguraikan jawaban ke dalam beberapa pernyataan dan mampu menarik kesimpulan dari pernyataan yang diberikan, sehingga dapat dikatakan siswa mampu menarik kesimpulan dari soal yang diberikan. Pada soal pertama yang memuat indikator kemampuan memeriksa kesahihan suatu argumen, siswa belum sepenuhnya mampu menguraikan jawaban dengan tepat dan tanpa disertai suatu bukti, sehingga siswa belum mampu memeriksa kesahihan suatu argumen dengan tepat. Pada soal kelima yang memuat indikator kemampuan dalam menemukan pola penyelesaian, beberapa siswa sudah mampu sepenuhnya dalam menguraikan informasi yang ada pada soal menjadi sebuah pola permisalan, sehingga siswa mampu menemukan pola penyelesaian pada suatu gejala matematis dengan tepat.

\section{Kemampuan Penalaran Adaptif dengan Keaktifan Belajar Rendah}

Siswa dengan keaktifan belajar rendah masih bingung dalam memahami soal. Sering kali siswa menuliskan dan menjelaskan dengan tidak lengkap atau menuliskan kembali soal yang dikerjakan. Pada soal keempat yang memuat indikator mengajukan dugaan atau hipotesis, siswa cenderung tidak mampu menuliskan dengan tepat bagaimana persamaan kedua terbentuk, sehingga meskipun jawaban siswa bisa dikatakan benar tetapi kebenaran dari dugaan yang dituliskan belum bisa dibuktikan. Pada soal ketiga yang memuat indikator kemampuan dalam memberikan alasan, siswa juga belum mampu memberikan alasan yang tepat, siswa hanya menuliskan kembali soal yang dipertanyakan. Dari hal tersebut dapat dikatakan siswa tidak mampu memberikan alasan secara jelas tentang jawaban yang diberikan. Pada soal kedua yang memuat indikator kemampuan dalam menarik kesimpulan, siswa belum mampu memberikan pernyataan jawaban dengan tepat sehingga kesimpulan yang diperoleh tidak sesuai pernyataanpernyataan yang ada pada lembar jawaban. Pada soal pertama yang memuat indikator mampu memeriksa kesahihan atau kebenaran suatu argumen, beberapa siswa ada yang sudah tepat dalam menguraikan bukti kebenaran dari pernyataan yang ditulis, sehingga dapat dikatakan siswa sudah mampu memeriksa kesahihan atau kebenaran suatu argumen. Pada soal kelima yang memuat indikator mampu dalam menemukan pola penyelesaian, siswa mampu menuliskan jawaban dengan menggunakan permisalan meskipun jawaban yang diberikan masih belum tepat. Dapat dikatakan siswa mampu menemukan pola pada suatu gejala matematis dengan tepat.

\section{Simpulan}

Berdasarkan uraian di atas, dapat diambil beberapa kesimpulan siswa dengan keaktifan belajar tinggi mampu menguasai tiga dari lima indikator kemampuan penalaran adaptif. Kebanyakan siswa dengan keaktifan belajar tinggi sudah paham dengan pertanyaan yang ada pada soal, akan tetapi belum mampu dalam memberikan alasan mengenai jawaban yang diberikan dan memeriksa kesahihan dari suatu argumen. Hal ini ditandai dengan siswa yang memiliki 
keaktifan belajar tinggi masih sedikit kesulitan dalam mengembangkan argumen matematika untuk membuktikan suatu pernyataan serta belum maksimalnya usaha siswa untuk berusaha mencari informasi atau pengetahuan yang dimiliki untuk pemecahan masalah. Siswa dengan keaktifan belajar sedang belum mampu menguasai semua indikator, beberapa siswa hanya menguasai tiga dari lima indikator kemampuan penalaran adaptif. Siswa dengan keaktifan belajar tinggi belum mampu menguasai indikator mampu dalam memberikan alasan mengenai jawaban yang diberikan dan memeriksa kesahihan suatu argumen. Hal ini ditandai dengan masih belum pahamnya siswa dengan pertanyaan yang ada pada soal, sehingga beberapa siswa hanya menjawab dengan tidak lengkap atau menulis kembali soal yang ditanyakan. Siswa dengan keaktifan belajar rendah hanya mampu menguasai dua dari lima indikator kemampuan penalaran adaptif. Siswa belum mampu dalam mengajukan dugaan atau hipotesis dari informasi yang diketahui. Siswa juga belum mampu dalam memberikan alasan mengenai jawaban yang diberikan serta menarik kesimpulan dari suatu pernyataan.

\section{Daftar Pustaka}

Depdiknas. (2006). Permendiknas No 21 Tahun 2016 tentang Standar Isi. Depdiknas. Jakarta. Donovan, S. (2016). How Students Learn: History, Mathematics, and Science in The Classroom. The National Academies Press. Washington, DC.

Hamalik, O. (2006). Proses Belajar Mengajar. PT. Bumi Perkasa. Jakarta.

Haryanti, M. D. \& Wibowo, T. (2016).Proses Penalaran Adaptif (Adaptive Reasoning) Dalam Pemecahan Masalah Matematika Pada Siswa SMP.Ekuivalen-Pendidikan Matematika, 21(1).

Herniyati. (2017). Analisis Kemampuan Penalaran Adaptif Matematis Siswa Kelas VII SMP Negeri 2 Karangpucung Ditinjau dari Rasa Percaya Diri. Skripsi pada Sarjana Universitas Muhammadiyah Purwokerto: tidak diterbitkan.

Kristanti, Y.D. \& Kriswandani. (2018). Analisis Penalaran Adaptif dalam Menyelesaikan Soal Polyhedron Ditinjau dari Gaya Belajar dan Gaya Berpikir. Prosiding Seminar Nasional Etnomatnesia. $\quad$ http://www.jurnal.ustjogja.ac.id/index.php/etnomatnesia/article/view/ 2323/1286.

Maharani, F. R. \& Rosyidi, A. H. (2018). Profil Penalaran Adaptif Siswa dalam Memecahkan Masalah Matematika Berdasarkan Gaya Kognitif Visualizer-Verbalizer. MATHEdunesa, 7(2), 363-370.

National Research Council. (2001). Adding it up: Helping children learn mathematics.J. Kilpatrick, J.Swafford, and B. Findell (Eds.). National Academy Press. Washington, DC.

Novasari. (2017). Deskripsi Kemampuan Pemecahan Masalah Matematis Ditinjau dari Keaktifan Belajar Siswa Kelas VIII SMP Muhammadiyah 1 Purwokerto. Skripsi pada Sarjana Universitas Muhammadiyah Purwokerto: tidak diterbitkan.

Permendikbud. (2016). Permendikbud No 24 Lampiran 15 tentang Kompetensi Isi dan Kompetensi Dasar Matematika SMP/MTs. Kemendikbud. Jakarta.

Priatna, N. (2012). Penalaran Matematika. Jurnal Pendidikan Matematika [Online]. Tersedia:http://file.upi.edu/Direktori/FPMIPA/JUR._PEND._MATEMATIKA/1963033 11988031-NANANG_PRIATNA/Penalaran_Matematika.pdf [6 Mei 2019].

Sa'diyah, I. F. \& Siswono, T. Y. E. (2018). Penalaran Adaptif Siswa Reflektif dan Impulsif dalam Mengajukan Soal Matematika. MATHEdunesa, 7(2), 290-298.

Santrock, J. (2010). Psikologi Pendidikan. Kencana. Jakarta.

Sudjana, Nana. (1989). Dasar-dasar Proses Belajar Mengajar. Penerbit Sinar Baru. Bandung. Sugiyono. (2016). Metode Penelitian Kuantitatif, Kualitatif, dan R\&D. Alfabet. Bandung. 